\section{Nauplius}

The Journal OF The Brazilian Crustacean Society

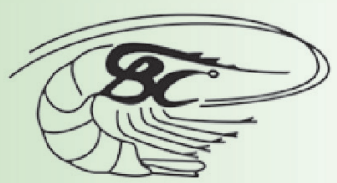

e-ISSN 2358-2936

www.scielo.br/nau www.crustacea.org.br

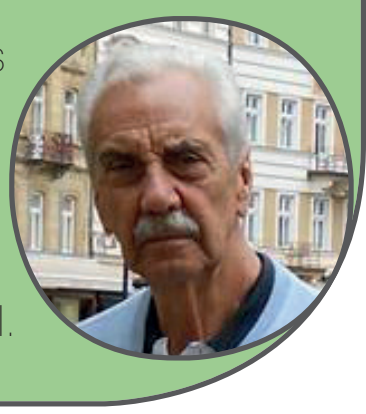

\title{
Morphological review of the freshwater fairy shrimp Dendrocephalus brasiliensis Pesta, 1921 (Anostraca: Thamnocephalidae)
}

Samara de Paiva Barros-Alves ${ }^{1,3}$, Douglas Fernandes Rodrigues Alves $^{1,3}$, Eduardo Antônio Bolla Jr ${ }^{2,3}$, Nicolas Rabet ${ }^{4,5}$ and Gustavo Luis Hirose ${ }^{1,3}$

1 Universidade Federal de Sergipe, Departamento de Biologia, Laboratório de Carcinologia. Av. Marechal Rondon, s/n, Rosa Elze. 49100-000 São Cristóvão, Sergipe, Brazil.

SPBA E-mail: barros_samara@hotmail.com

DFRA E-mail: douglas_biologo@yahoo.com.br

GLH E-mail: gustavo_lh@hotmail.com

2 Instituto Federal de São Paulo - IFSP, Avaré, São Paulo, Brazil. EABJr E-mail: jubolla@yahoo.com.br

3 Group of Studies on Crustacean Biology, Ecology and Culture - NEBECC, Botucatu, São Paulo, Brazil.

4 Sorbonne Universités, UPMC Univ Paris 06, CNRS, Biologie des organismes et écosystèmes aquatiques (BOREA, UMR 7208), Muséum National d'Histoire naturelle, Université Pierre et Marie Curie, Université de Caen Basse-Normandie, CNRS, IRD, CP26 75231, 43 rue Cuvier Paris Cedex 05, France.

5 Universidade Estadual do Sudoeste da Bahia, Laboratório de Biossistemática Animal, UESB/DEBI, BR 415, km 03. 45700-000 Itapetinga, Bahia, Brazil.

NRE-mail: nicolas.rabet@snv.jussieu.fr

ZOOBANK http://zoobank.org/urn:1sid:zoobank.org:pub:9B1E093F-70EA-43F38B21-7DC51537A43E

CORRESPONDING AUTHOR Gustavo Luis Hirose

gustavo_Ih@hotmail.com

SUBMITTED 12 February 2016

ACCEPTED 22 May 2016

PUBLISHED 8 August 2016

Guest Editors

Maria Lúcia Negreiros-Fransozo and Adilson Fransozo

DOI 10.1590/2358-2936e2016008

\section{Abstract}

Information concerning the morphology of Dendrocephalus brasiliensis Pesta, 1921 is currently fragmented. This study reviewed the morphological structures described previously and new features (e.g., antenna-like structures and gonopod). We review the distribution of this species and also expand the geographic distribution of D. brasiliensis in the state of Alagoas. The specimens were obtained from fish-breeding tanks in Porto Real do Colégio, Alagoas, Brazil, in November 2012. Several morphological structures of $D$. 
brasiliensis are described in greater detail, including all branches and sub-branches from the frontal appendage and thoracopods from one population and compared to other species.

\section{KEY WORDS}

Crustacea, Branchiopoda, geographic distribution, temporary pools.

\section{INTRODUCTION}

The genus Dendrocephalus Daday, 1908 is currently represented by 17 valid species (Rogers, 2006; 2013) and is subdivided in two subgenera: Dendrocephalinus Rogers, 2006 and Dendrocephalus Daday, 1908. For the subgenus Dendrocephalus, 14 species are recognized, which are distributed in Central and South America, from Costa Rica to Argentina, as well as on the Galapagos and Caribbean islands (Rabet and Thiéry, 1996; Rabet, 2006; Rogers, 2006; Rogers et al., 2012). In Brazil, five species were recorded: Dendrocephalus brasiliensis Pesta, 1921, Dendrocephalus carajaensis Rogers et al., 2012, Dendrocephalus goiasensis Rabet \& Thiéry, 1996, Dendrocephalus orientalis Rabet \& Thiéry, 1996 and Dendrocephalus thieryi Rabet, 2006 (Chaves et al., 2011; Rogers et al., 2012), and another species that has not yet been formally described (Chaves et al., 2011).

In recent decades, a growing demand for alternative sources of food for aquaculture has attracted the interest of researchers to the genus Dendrocephalus (Cohen et al., 2014). Among the species that occur in Brazil, $D$. brasiliensis is notable for the increase in the number of published studies that address its use as a food source to replace Artemia Leach, 1819 (Yflaar and Olivera, 2003; Carneiro et al., 2004; Lopes et al., 2007).

Similar to other Anostraca, D. brasiliensis inhabits temporary pools, with resting eggs laid on the bottom of the pool (Brendonck et al., 2008). These eggs allow survival during the dry period but are also responsible for the dissemination of the species. To date, $D$. brasiliensis has been collected in natural and artificial Caatinga pools from the north of Minas Gerais to the north of Rio Grande do Norte and also in pools in Gran Chaco in northern Argentina. The species has also been collected in the more humid climate of coastal northeastern Brazil (Rabet and Thiéry, 1996). To date, the species has not been reported in the Cerrado biome. Dendrocephalus brasiliensis is found with several large branchiopods, such as $D$. orientalis in coastal Paraíba and D. cervicornis (Weltner, 1890) in northern Argentina (César, 1989; Rabet and Thiéry, 1996; César et al., 2004). Other large branchiopod species reported together with $D$. brasiliensis are Cyclestheria hislopi (Baird, 1859) (Lemos-de-Castro and Lima, 1986), Eulimnadia colombiensis Roessler, 1989 and Eulimnadia magdalensis Roessler, 1990 (NR, pers. obs.).

The morphology of $D$. brasiliensis was first described by Pesta (1921) and Lutz (1929) and was subsequently revised by Pereira (1983), Lemos-de-Castro and Lima (1986) and Rabet and Thiéry (1996). Although different authors have investigated the morphology of D. brasiliensis, most descriptions (Pesta, 1921; Lutz, 1929) were performed without the standardization of morphological terminology proposed by Belk and Pereira (1982) and Pereira (1983). In addition, the description of some structures, such as branch $1 \mathrm{~V}$ and branch $2 \mathrm{~A}$ of the frontal appendage and thoracopods require some additional observations (see Pereira, 1983; Lemos-de-Castro and Lima, 1986; Rabet and Thiéry, 1996). Currently, information on the morphology of $D$. brasiliensis is fragmented into different studies, making it difficult to use.

Given the great potential of D. brasiliensis for aquaculture and the possible expansion of its distribution into other regions, the correct identification of the species becomes of great importance. Thus, the objective of this study is to provide a review of D. brasiliensis, to compile and expand the already existing knowledge of morphology and to describe structures for which there is little information to date (e.g., antenna-like structures and gonopod). Moreover, a new record of the geographical distribution was provided for this species.

\section{Material and Methods}

The specimens were obtained from fish-breeding tanks of the Centro Integrado de Recursos Pesqueiros e 
Aquicultura (CERAQUA), which belongs to the Companhia de Desenvolvimento dos Vales do São Francisco e do Parnaíba - CODEVASF (10¹2’07.70”S $\left.36^{\circ} 47^{\prime} 30.43^{\prime \prime} \mathrm{W}\right)$, situated at an altitude of $10 \mathrm{~m}$ in the municipality of Porto Real do Colégio, Alagoas, in northeastern Brazil. The individuals were sampled with a plankton net (300- $\mu \mathrm{m}$ mesh size) on 23 November 2012.

Literature descriptions (Pesta, 1921; Lutz, 1929; Pereira, 1983; Lemos-de-Castro and Lima, 1986; Rabet and Thiéry, 1996) and identification keys (Rabet and Thiéry, 1996; Rabet, 2006; Chaves et al., 2011; Rogers et al., 2012; Hirose et al., 2015) were used for species identification. The present description was based on the observation of 60 individuals ( 40 males and 20 females). For detailed examinations, the specimens were dissected under a stereoscopic microscope and prepared on semi-permanent slides. Drawings of the appendages were made with an optical microscope (Axioskop 2, Zeiss) provided with a camera lucida. The specimens' total length was measured from the anterior margin of the head to the telson (excluding cercopods). The brood pouch was measured from the proximal portion (distal of postgenital abdominal segment IV) to the most distal portion. The resting eggs were measured as the largest diameter. The measurements were made with a stereomicroscope equipped with an imaging and measurement tool (Zeiss Stemi DV4, accuracy 0.1 $\mathrm{mm}$ ). The terminology of branches and sub-branches is based on Pereira (1983).

The material examined is deposited in the scientific collection of the Carcinology Laboratory of the Federal University of Sergipe (CARCINO) and in the crustacean collection of the Museum of Zoology of the University of São Paulo (MZUSP). Comparative materials are in the personal collection of Nicolas Rabet or in the National Museum of Rio de Janeiro (MNRJ).

\section{Systematics}

Order Anostraca Sars, 1867

Family Thamnocephalidae Linder, 1941

Genus Dendrocephalus Daday, 1908

\section{Subgenus Dendrocephalus Daday, 1908}

\section{Dendrocephalus (Dendrocephalus) brasiliensis Pesta, 1921}

Material examined. Alagoas-Porto Real do Colégio, fish tank, 15 males and 10 females, collected by M.F.G. Brito, 23 November 2012 (CARCINO 104); 11 males and 10 females, same data (MZUSP 32913).

Additional material examined. Rio Grande do Norte-Caicó, fish tank, 10 specimens, collected by N. Rabet, 6 August 1993 (MNRJ 3000); Mossoró, ESAM, two specimens, collected by Lemos de Castro and P. Coelho, 27 February 1980 (MNRJ 3007). Paraíba-João Pessoa: temporary pools, 10 specimens, collected by N. Rabet, 18 July 1993 (MNRJ 3002). Minas GeraisJanuária, temporary pool, two specimens, collected by W. Costa, G. Brasil and C. Campinha, 7 February 1994; two specimens, collected by J. Goma Pinto and D. Pillet, 6 February 2003. Ceará-Brejo Santo, Açude Atalhos, four specimens, collected by U. Caramaschi, R.N. Feio and H. De Nieweyer, 6 December 1998 (MNRJ 15893).

Distribution. To date, this species was recorded in Brazil (Piauí, Ceará, Rio Grande do Norte, Paraíba, Bahia, Minas Gerais and São Paulo) (Lemos-de-Castro and Lima, 1986; Rabet and Thiéry, 1998; Mai et al., 2008; Chaves et al., 2011) and northern Argentina (César, 1989; César et al., 2004).

The occurrence of $D$. brasiliensis in fish-breeding tanks in the Porto Real do Colégio represents the first record of this species in the state of Alagoas. Two main hypotheses should be considered for the current record of these populations in Alagoas: 1) associated with the natural distribution of the species, even if it is not found yet in natural ponds in this state; or 2) introduced by human action in connection with aquaculture.

Dendrocephalus brasiliensis is typically found in temporary ponds in the Caatinga biome and in a coastal area (at João Pessoa, Paraíba, see Rabet and Thiéry, 1996). The distribution of this species appears to be interrupted in Bahia state (Fig. 1). This apparent gap should be confirmed by a precise examination of many dendrocephalid populations, because Dendrocephalus orientalis is clearly dominant in the center of Bahia, 


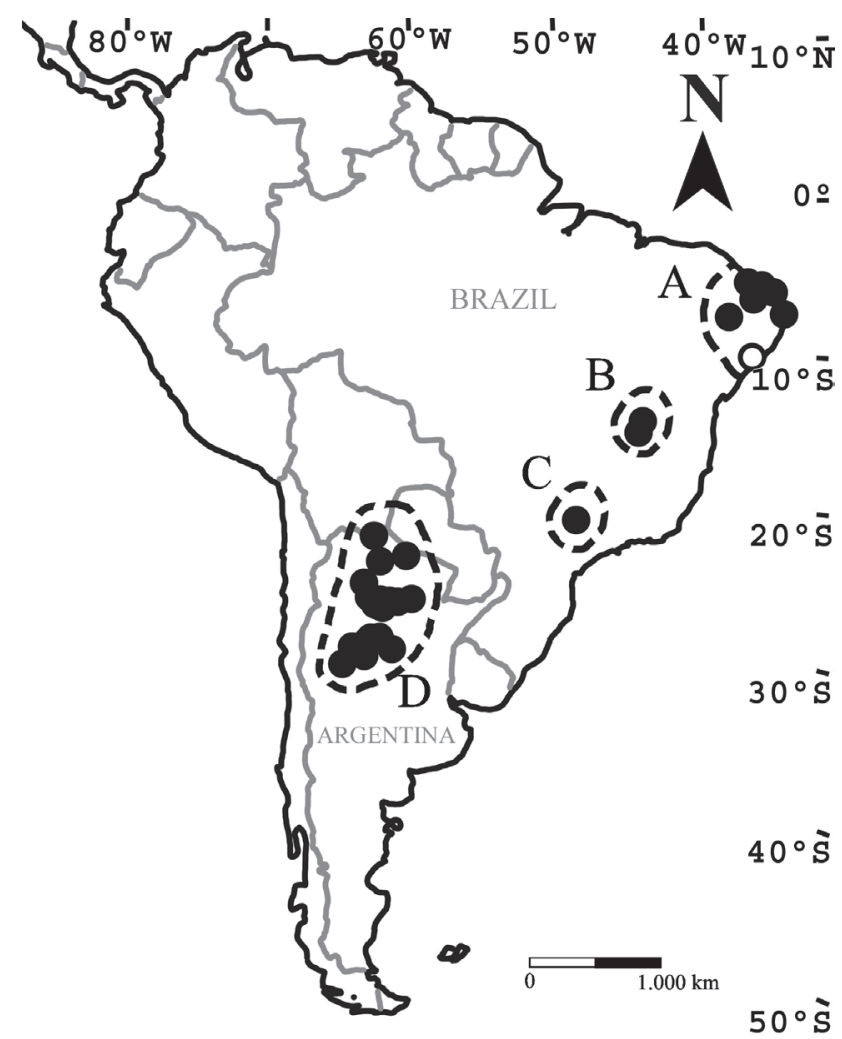

Figure 1. Distribution of the fairy shrimp Dendrocephalus brasiliensis Pesta, 1971. Full circles correspond to sites of occurrence. Empty circles correspond to the new record for the present study (Porto Real do Colégio, Alagoas state). A) Piauí, Ceará, Rio Grande do Norte and Paraíba states; B) Bahia and Minas Gerais states; C) São Paulo state; D) northern Argentina. References: Lemos-de-Castro and Lima (1986), César (1989), Rabet and Thiéry (1998), César et al. (2004), Mai et al. (2008), Chaves et al. (2011).

but we cannot exclude a sympatric distribution of the second species.

In addition to its natural distribution, the expansion of the geographical distribution of $D$. brasiliensis might be associated with fish-breeding tanks. Dendrocephalus brasiliensis and D. orientalis were collected twice in fish tanks (Rabet and Thiéry, 1996; 1998; this study), and this activity might have a major impact on the distribution of the species. Particularly, this can generate predictions of the rapid expansion of D. brasiliensis into other hydrographic basins, which might cause problems related to the introduction of exotic species (Rocha et al., 2005; Mai et al., 2008).

Redescription. Males (total length: 13.2-16.9 mm; mean length: $15.26 \pm 0.71 \mathrm{~mm})$. Eyes pedunculate, ovoid in lateral view, without posterior spines (Fig.
2A). Antenna-like outgrowths slender (Fig. 2B) lying between first antennae and second antennae. First antennae (Fig. 2C) cylindrical, elongated, and smooth, almost as long as second antennae. Second antennae (Fig. 2D) with proximal antennomeres fused basally on anterior region of head. Proximal antennomere bears stout and smooth digitiform process mediodistally. Distal antennomere weakly sclerotized, smooth, and evenly curved medially, with acute terminus. Basal part of arms frontal appendage (Fig. 2E) lacking spines at anterior margin and with row of medial spines extending to terminal branches. Frontal appendage branch $1 \mathrm{~V}$ distally ramified into two sub-branches, both with longitudinal row of medial spines (Fig. $3 \mathrm{~A})$. Posterior sub-branch with $0-2$ short subterminal spines ending acutely in one hook-shaped spine (Fig. 3a1). Anterior sub-branch longer than the posterior counterpart and broadening distally with 3-7 robust spines on posterior margin and 1-2 larger spines at tip (Fig. 3a2). Frontal appendage branch 2D with three sub-branches: I, II and III (from posterior to anterior, respectively) (Fig. 3B). Sub-branch I with row of short spines on anterolateral margin, ending acutely with 2-3 long spines in medial portion. Sub-branch II almost half size of sub-branch I, ending acutely with $0-1$ short

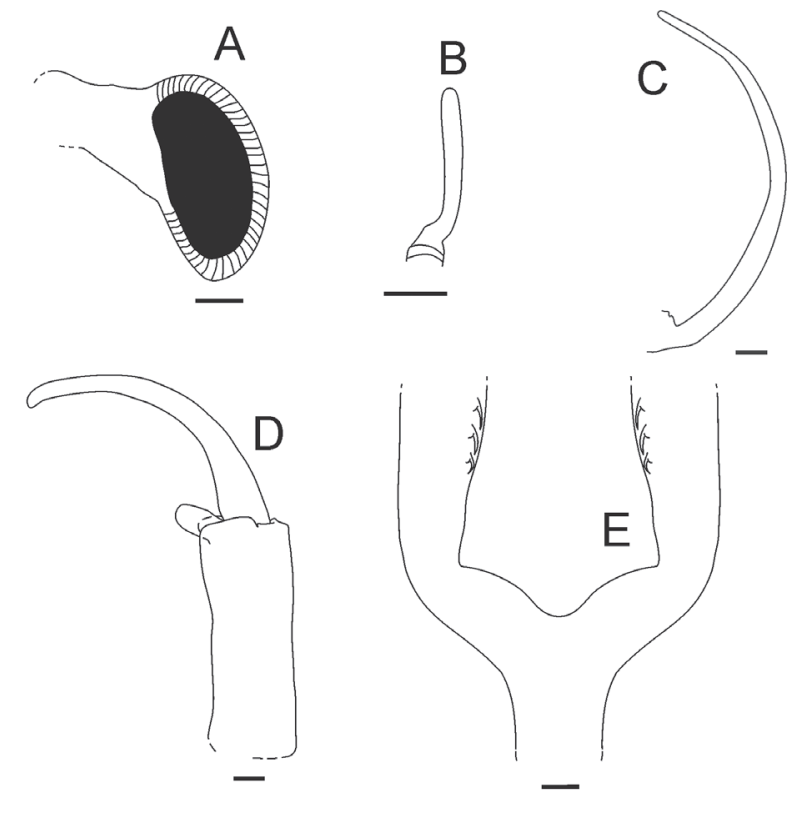

Figure 2. Dendrocephalus brasiliensis Pesta, 1971, male from Porto Real do Colégio, Alagoas, Brazil (CARCINO 104).A) male pedunculate eye; B) antenna-like structure; C) first antenna; D) second antenna; E) basal part of the arms. Scale bars $=0.2 \mathrm{~mm}$. 


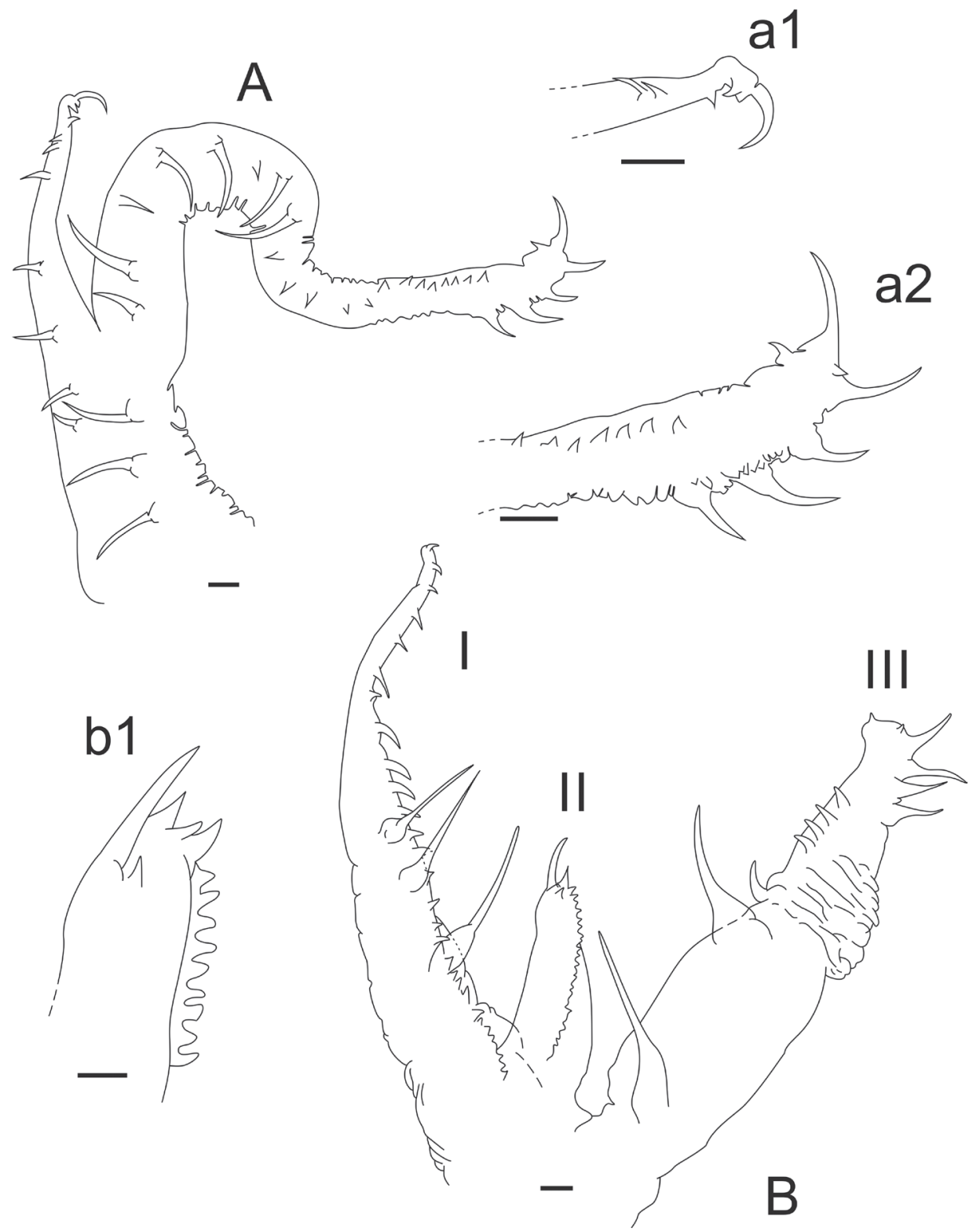

Figure 3. Dendrocephalus brasiliensis Pesta, 1971, male from Porto Real do Colégio, Alagoas, Brazil (CARCINO 104). A) branch $1 \mathrm{~V}$, with distal portion of the anterior sub-branch (a1) and distal portion of the posterior sub-branch (a2); B) branch 2D with subbranches I, II and III and details of the distal portion of sub-branch II (b1). Scale bars $=0.1 \mathrm{~mm}$.

sub-terminal spines, one long spine and 1-2 robust spines (Fig. 3b1). Sub-branch III roughly equal to sub-branch I (sometimes shorter or longer) but with almost twice basal diameter, cylindrical proximally and flattened distally, bearing large spiniform process proximally. Distal flattened portion with row of 3-4 spines at posterolateral margin, 2-6 robust spines at anterolateral margin, $0-2$ short subterminal spines and 0-1 minimal spine on tip. Frontal appendage branch 2A (Fig. 4A, 4a1) cylindrical and heavily sclerotized on its anterior podiform end (Fig. 4a2), presenting one bulging basal cell pad more laterally and one basal long spine (Fig. 4a3). Frontal appendage branch 2V cylindrical, abruptly narrowed, and usually bent distally (Fig. 4b1), with 3-5 well-defined cell pads in median portion, another parallel medial-anterior row of 3-5 smaller cell pads, and anterior scattered minimal and shapeless cell pads (Fig. 4b2); it ends at tip in cluster of 5-7 hand-like aligned cell pads (Fig. 4b3).

Thoracopods with pre-epipods with finely serrated contours (Fig. 5A). Endopods of thoracopods without basolateral lobe and without pronounced distolateral border. Endopods of limbs one, two and three marginally ornamented with, respectively, 5-7, 

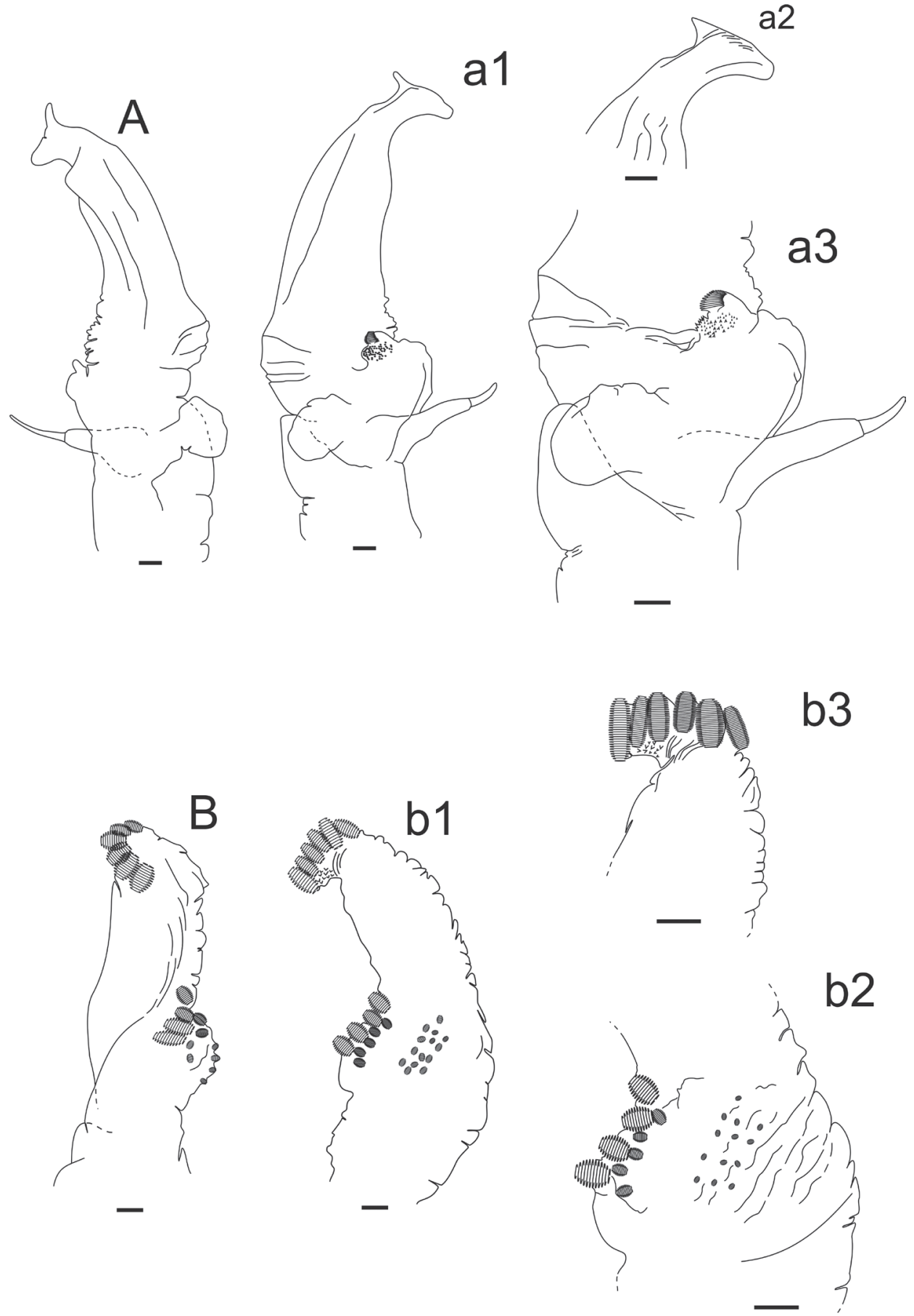

Figure 4. Dendrocephalus brasiliensis Pesta, 1971, male from Porto Real do Colégio, Alagoas, Brazil (CARCINO 104). A) branch $2 \mathrm{~A}$, rotated $180^{\circ}(\mathrm{a} 1)$, details of the anterior end (a2) and basal spine and basal cell pad (a3); B) branch $2 \mathrm{~V}$, with branch rotated $90^{\circ}$ (b1), showing the medial and medial-anterior rows of cell pads (b2) and details of cell pads in the bulge (b3). Scale bars $=0.1 \mathrm{~mm}$.

15-19 and 9-13 spines and 21-25, 26-29 and 27-33 setae, most of these plumose (Fig. 5B, C and D).

Gonopod (retracted state) with basal part short, with slightly curved triangular lateral projection containing small spines and surface protuberances, as well as pointed end portion. Distal end of retracted gonopod globose and nude, with small groove at tip
(Fig. 6A).

Females shorter than males (total length: 11.9-14.5 $\mathrm{mm}$; mean length: $13.27 \pm 0.72 \mathrm{~mm})$. Antennae short, flat and rounded at tip. Endopods of thoracopods morphologically similar. Brood pouch elongated (Fig. 6B). Cercopods plumose. Brood-pouch length: 3.4-4.7 $\mathrm{mm}(4.15 \pm 0.32 \mathrm{~mm})$. Resting eggs (mean diameter: 

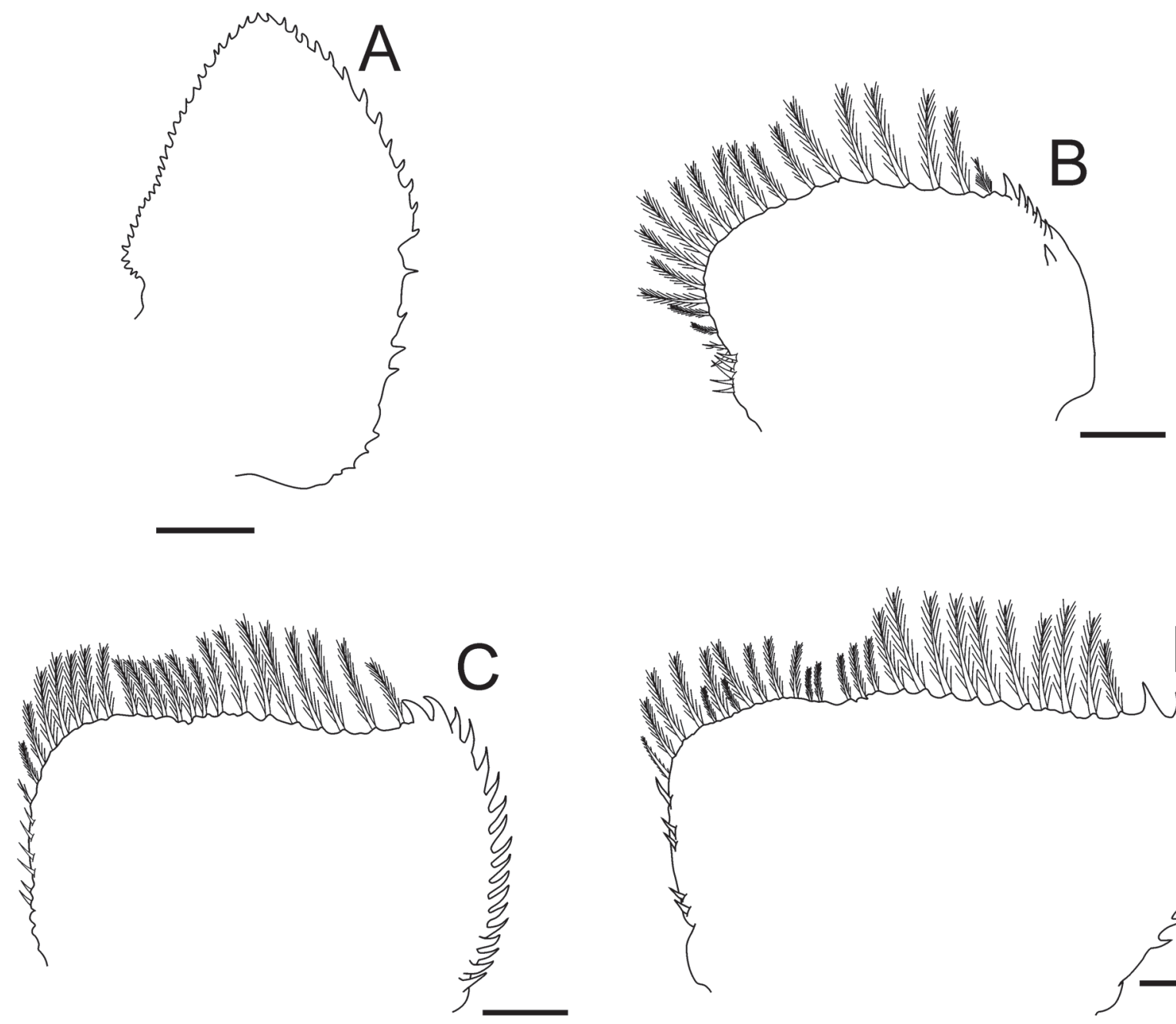

Figure 5. Dendrocephalus brasiliensis Pesta, 1971, male from Porto Real do Colégio, Alagoas, Brazil (CARCINO 104). A) preepipodite of first limb; B) endopodite of the first limb; C) endopodite of the second limb; D) endopodite of the third limb. Scale bars $=0.2 \mathrm{~mm}$.

$208.4 \pm 11.3 \mu \mathrm{m})$ polyhedral with rounded ridges (Fig. 6C), intersecting to form large polygons with circular depressions, sometimes, with small polygons in addition to large depressions.

Remarks. Some features have been described here for the first time, such as antenna-like structures and the gonopod (retracted state). Furthermore, some morphological characteristics that were previously described superficially were examined in more detail (e.g., the endopod of thoracopods, the number of spines on branch $1 \mathrm{~V}$ and sub-branches I, II and III of branch $2 \mathrm{D}$, the number of cell pads in branch $2 \mathrm{~V}$ ).

When compared to other species of the genus, spines were not observed on the proximal anterior surface of the male frontal appendage arms, similar to Dendrocephalus carajaensis, Dendrocephalus geayi
(Daday, 1908), Dendrocephalus sarmentosus Pereira \& Belk, 1987 and Dendrocephalus venezolanus Pereira, 1984 (Pereira, 1983; 1984; Pereira and Belk 1987; Rogers et al., 2012). Other species, such as Dendrocephalus affinis Pereira, 1984, Dendrocephalus goiasensis, D. orientalis, Dendrocephalus spartaenovae Margalef, 1961 and Dendrocephalus thieryi, may have one or more spines on each arm (Pereira, 1983; Rabet and Thiéry, 1996; Rabet, 2006; Cohen et al., 2014; Hirose et al., 2015). Furthermore, spines were not observed in the eyes of $D$. brasiliensis, similar to $D$. sarmentosus (see Pereira and Belk, 1987), D. carajaensis (see Rogers et al., 2012) and some individuals of $D$. orientalis (see Hirose et al., 2015).

In branch $1 \mathrm{~V}$, the anterior sub-branch is longer than the posterior branch and the distal portion is swollen, as in D. affinis (see Cohen et al., 2014), D. 

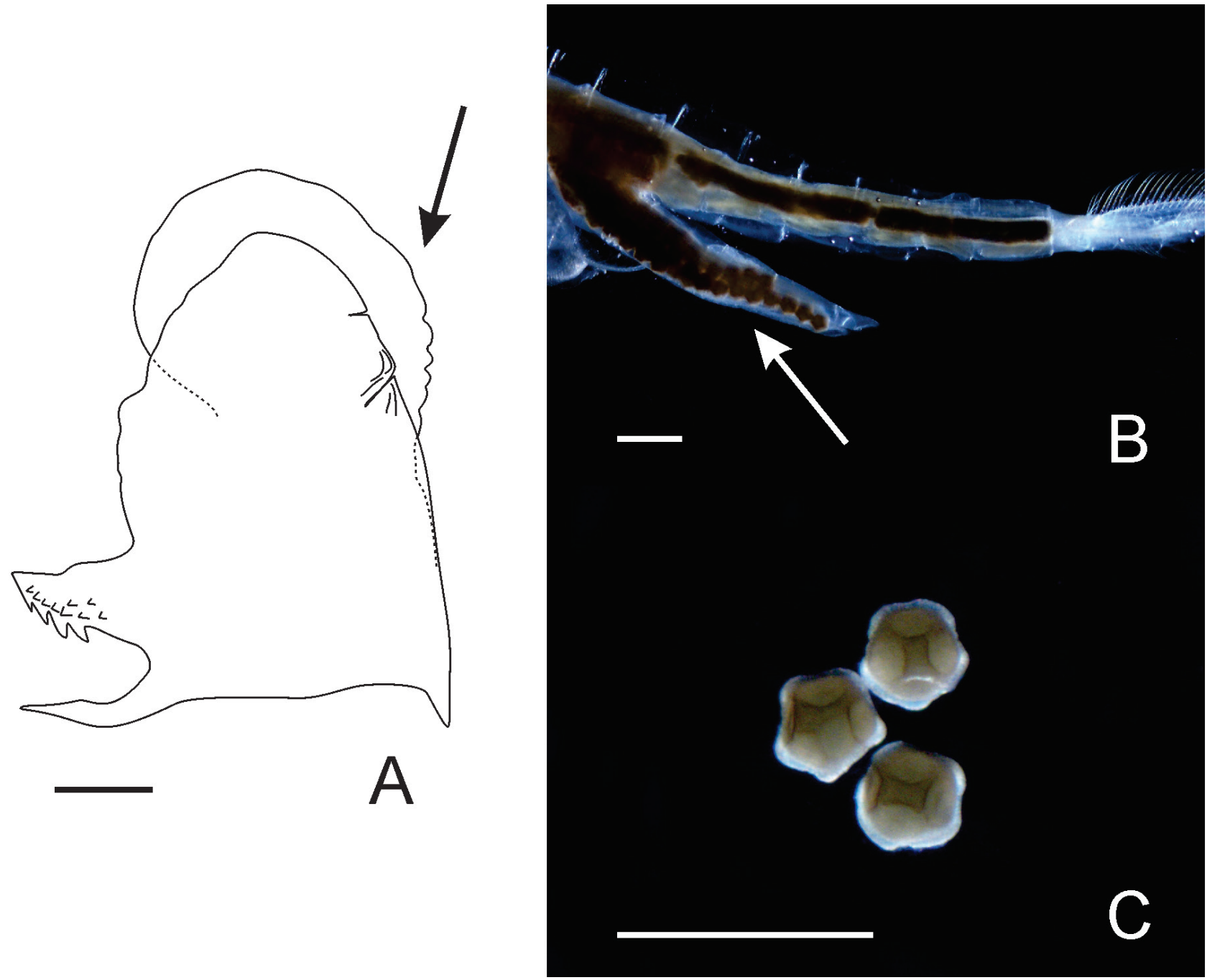

Figure 6. Dendrocephalus brasiliensis Pesta, 1971 from Porto Real do Colégio, Alagoas, Brazil (CARCINO 104). A) non-everted gonopod lateral view; B) brood pouch; C) polyhedral resting eggs with rounded ridges. Scale bars $=0.2 \mathrm{~mm}$. The arrow indicates the nude appearance, with a small groove at the tip of the distal end of the retracted gonopod.

carajaensis (see Rogers et al., 2012), Dendrocephalus cervicornis (see Pereira, 1983), Dendrocephalus cornutus Pereira \& Belk, 1987 (see Pereira and Belk, 1987), D. geayi (see Pereira, 1983), D. orientalis (see Rabet and Thiéry, 1996; Hirose et al., 2015), D. thieryi (see Rabet, 2006) and D. venezolanus (see Pereira, 1984). This morphology differs from other species, such as D. goiasensis (see Rabet and Thiéry, 1996) and Dendrocephalus argentinus Pereira \& Belk, 1987 (see Pereira and Belk, 1987), which display an acute distal portion. The main particularity of branch $2 \mathrm{D}$ is the presence of several small spines on the distal third of sub-branch III. This morphological characteristic is also shared with $D$. affinis, D. orientalis and $D$. thieryi (see Rabet and Thiéry, 1996; Rabet, 2006; Cohen et al., 2014; Hirose et al., 2015).
Branch 2A shows a strong column extending in one or two projections and a cell pad at the base, as already observed for other dendrocephalids; the distal end is podiform as in D. affinis (see Cohen et al., 2014), Dendrocephalus conosuris Pereira \& Ruiz, 1995 (see Pereira and Ruiz, 1995), D. cornutus (see Pereira and Belk, 1987), D. goiasensis (see Rabet and Thiéry, 1996), D. spartaenovae (see Pereira, 1983) and D. thieryi (see Rabet, 2006), but differs from the hookshaped projection described for other species, such as D. orientalis (see Rabet and Thiéry, 1996; Hirose et al., 2015) and D. carajaensis (see Rogers et al., 2012).

Branch $2 \mathrm{~V}$ is typically bent at the tip and terminates in several well-defined cell pads (3-5), which are frequently found in the subgenus Dendrocephalus but differ in D. carajaensis (see Rogers et al., 2012) and D. 
sarmentosus (see Pereira and Belk, 1987), which share only two cells pads in the distal portion.

In D. brasiliensis, the first two pairs of thoracopod endopods display no clear spinous laterodistal expansions and basolateral lobes, similar to $D$. sarmentosus (see Pereira and Belk, 1987) and D. carajaensis (see Rogers et al., 2012). The presence of basolateral lobes in the first two pairs of thoracopods is very common in the subgenus Dendrocephalus, as observed for D. orientalis (see Rabet and Thiéry, 1996; Hirose et al., 2015), D. goiasensis (see Rabet and Thiéry, 1996) and D. thieryi (see Rabet, 2006).

\section{DISCUSSION}

The morphology of Dendrocephalus brasiliensis has been completely revised in this study. Some of the structures that have been newly described here, such as eyes, first and second antenna, branches and sub-branches of the frontal appendage, thoracopod endopods 1-3 and eggs, are similar to previously described structures (Pesta, 1921; Lutz, 1929; Pereira, 1983; Lemos-de-Castro and Lima, 1986; Rabet and Thiéry, 1996).

Traditionally, the identification of $D$. brasiliensis was supported by the absence of spines on the anterior portion of the male frontal appendage arms (Rabet, 2006; Chaves et al., 2011). However, Hirose et al. (2015) demonstrated for Dendrocephalus orientalis that such morphological characteristics can vary among individuals of the same species, as was also verified for Dendrocephalus affinis by Cohen et al. (2014), reinforcing the need to use other morphological characteristics that can be used for species identification. According to Hirose et al. (2015), important morphological features for identification of $D$. brasiliensis are: 1) branch $2 \mathrm{~A}$ podiform; 2) second thoracopod endopodite without basolateral spine; 3 ) first thoracopod endopodite without basolateral lobe; and 4) branch $1 \mathrm{~V}$ anterior sub-branch with distal portion swollen. Therefore, the need of accurate morphological descriptions of Dendrocephalus species is evident, as well as a standardization of the descriptive process, so that the characteristics of diagnostic importance and its details can be adequately described, enabling interspecific comparisons.

Morphologically, the populations of $D$. brasiliensis studied appear to be relatively homogeneous in relation to the frontal appendage, the legs and the basal part of the gonopod. Nevertheless, D. brasiliensis is clearly more widely distributed than other dendrocephalid species and might be composed of several cryptic species. Particular attention should be focused in the future to understand the distribution of populations of these species, especially in Argentina.

\section{ACKNOWLEDGMENTS}

The authors dedicate this study to Dr. Nilton José Hebling, who had a crucial role in the NEBECC (Group of Studies on Crustacean Biology, Ecology and Culture) foundation, acting directly and indirectly in the education of several carcinologists in Brazil, including SPBA, DFRA, EABJ and GLH. The authors thank the Centro Integrado de Recursos Pesqueiros e Aquicultura (CERAQUA), belonging to the Companhia de Desenvolvimento dos Vales do São Francisco e do Parnaíba (CODEVASF), M.Sc. Sergio Antônio Medeiros Marinho and Dr. Marcelo Fulgêncio Guedes de Brito for kindly providing the animals used in this study.

\section{References}

Baird, W. 1859. Description of some new recent Entomostraca from Nagpur, collected by the Rev. S. Hislop. Proceedings of the Royal Society of London Series B - Biological Sciences, 63: 231-234.

Belk, D. and Pereira, G. 1982. Thamnocephalus venezuelensis, new species (Anostraca: Thamnocephalidae), first report of Thamnocephalus in South America. Journal of Crustacean Biology, 2(2): 223-226.

Brendonck, L.; Rogers, D.C.; Olesen, J.; Weeks, S. and Hoeh, W.R. 2008. Global diversity of large branchiopods (Crustacea: Branchiopoda) in freshwater. Hydrobiologia, 595: 167-176.

Carneiro, R.L.; Silva, J.A.M.; Albinati, R.C.B.; Socorro, E.P. and Neves, A.P. 2004. Uso do microcrustáceo branchoneta (Dendrocephalus brasiliensis) na ração para tucunaré. Revista Brasileira de Saúde e Produção Animal, 5(1): 18-24.

César, I.I. 1989. Comparative study on the resting eggs of several anostracans (Crustacea). Key for the determination of the species based upon the egg structure and diameter. Studies on Neotropical Fauna and Environment, 24(4): 169-181.

César, I.I.; Armendáriz, L.C.; Becerra, R.V. and Liberto, R. 2004. Biodiversidad de Crustacea (Anostraca, Notostraca, Spinicaudata, Laevicaudata, Ostracoda, Amphipoda y Brachyura Trichodactylidae) de la Mesopotamia argentina. Insugeo, Miscelánea, 12: 247-252.

Chaves, T.P.; Lacau, S. and Rabet, N. 2011. Illustrated key to the Brazilian Dendrocephalus (Crustacea: Anostraca: Thamnocephalidae). Nauplius, 19(1): 1-5. 
Cohen, R.G.; Serna-Macías, D. and Eslava-Eljaiek, P. 2014. Redescription of Dendrocephalus affinis (Anostraca, Thamnocephalidae): first record of the species from Colombia and additional morphological observations useful in taxonomy. Journal of Crustacean Biology, 34(1): 82-89.

Daday de Dees, E. 1908. Diagnoses praecursoriae specierum aliquot novarum e familia Branchiopodidae. Annales de Sciences Naturelles, neuvème série, Zoologie, 7: 137-150.

Hirose, G.L.; Barros-Alves, S.P.; Alves, D.F.R.; Silva, I.R.S. and Bezerra, M.A.O. 2015. Morphological variation in males of Dendrocephalus orientalis (Anostraca: Thamnocephalidae): Implications for species identification. Zootaxa, 3915(4): 569-580.

Leach, W.E. 1819. Entomostracés. p. 524-543. In: F.G. Levrault (ed) Dictionnaire des Sciences naturelles. Tome XIV. Paris \& Strasbourg.

Lemos-de-Castro, A. and Lima, I.M.B. 1986. Sobre um crustáceo anostráceo reencontrado no estado do Rio Grande do Norte, Brasil (Crustacea, Branchiopoda). Anais do VII Congresso Brasileiro de Zoologia, Publicações Avulsas do Museu Nacional, 66: 43-54.

Linder, F. 1941. Contributions to the morphology and the taxonomy of the Branchiopoda Anostraca. Zoologiska Bidrag från Uppsala, 20: 101-303.

Lopes, J.P.; Gurgel, H.C.B.; Gálvez, A.O. and Pontes, C.S. 2007. Produção de cistos de "branchoneta" Dendrocephalus brasiliensis (Crustacea: Anostraca). Biotemas, 20(2): 33-39.

Lutz, A. 1929. Duos phyllopodos, observados no Rio Grande do Norte. Memorias del Instituto Oswaldo Cruz, 5: 3-9.

Mai, M.G.; Silva, T.A.S.; Almeida, V.L.S. and Serafini, R.L. 2008. First record of the invasion of Dendrocephalus brasiliensis Pesta, 1921 (Crustacea: Anostraca: Thamnocephalidae) in São Paulo State, Brazil. Pan-American Journal of Aquatic Sciences, 3(3): 269-274.

Margalef, R. 1961. La vida en los charcos de agua dulce de Nueva Esparta (Venezuela). Memoria de la Sociedad de Ciencias Naturales La Salle, 21: 75-110.

Pereira, G. 1983. Taxonomic importance of the frontal appendage in the genus Dendrocephalus (Anostraca: Thamnocephalidae). Journal of Crustacean Biology, 3(2): 293-305.

Pereira, G. 1984. Two new species of Dendrocephalus (Anostraca: Thamnocephalidae) from Venezuela. Journal of Crustacean Biology, 4(1): 147-153.

Pereira, G. and Belk, D. 1987. Three new species of Dendrocephalus (Anostraca: Thamnocephalidae) from Central and South America. Journal of Crustacean Biology, 7(3): 572-580.
Pereira, G.A. and Ruiz, L. 1995. A new species of Dendrocephalus (Anostraca, Thamnocephalidae) from Argentina. Crustaceana, 68(5): 567-574.

Pesta, O. 1921. Kritische Revision der Branchipodidensammlung des Wiener Naturhistorischen Staatsmuseum. Annalen des Naturhistorischen Museums in Wien, 34: 80-98.

Rabet, N. 2006. A new species of Brazilian Dendrocephalus (Anostraca, Thamnocephalidae). Zootaxa, 1370: 49-57.

Rabet, N. and Thiéry, A. 1996. The neotropical genus Dendrocephalus (Crustacea: Anostraca: Thamnocephalidae) in Brazil (South America), with a description of two new species. Journal of Natural History, 30(4): 479-503.

Rabet, N. and Thiéry, A. 1998. Branchiopoda Anostraca and Spinicaudata. p. 3-10. In: P.S. Young (ed), Catalogue o Crustacea of Brazil. Série Livros n 6 . Rio de Janeiro, Museu Nacional.

Rocha, O.; Espíndola, E.L.G.; Fenerich-Verani, N.; Verani, J.R. and Rietzler, A.C. 2005. Espécies invasoras em águas doces estudos de caso e propostas de manejo. Universidade Federal de São Carlos, São Carlos, 416p.

Roessler, E.W. 1989. Estudios sobre los entomotráceos de Colombia III. Estudio taxonómico de un nueva especie colombiana Eulimnadia colombiensis (Arthropoda, Crustacea, Conchostraca). Caldasia, 16: 58-65.

Roessler, E.W. 1990. Estudios sobre los Entomostráceos de Colombia II. Una nueva especie de Eulimnadia Packard 1874 (Crustacea, Conchostraca). Revista de la Academia Colombiana de Ciencias Exactas, Fisicas y Naturales, 17(66): 595-603.

Rogers, D.C. 2006. Agenus level revision of the Thamnocephalidae (Crustacea: Branchiopoda: Anostraca). Zootaxa, 1260: 1-25.

Rogers, D.C. 2013. Anostraca catalogus (Crustacea: Branchiopoda). The Raffles Bulletin of Zoology, 61(2): 525546.

Rogers, D.C.; Corrêa-Gomes, J.P. and Vieira, F. 2012. A new species of Dendrocephalus (Crustacea, Anostraca) from Serra dos Carajás (Pará State, Brasil). Zootaxa, 3363: 52-58.

Sars, G.O. 1867. Histoire naturelle des Crustacés d'eau douce Norvège. $1^{\mathrm{e}}$ Livraison, Les Malacostracés, Christiania, Imprimerie de Chr. Johnsen, 145p, 10 pl..

Weltner, W. 1890. Branchipus (Chirocephalus) cervicornis, n. sp. aus Südamerika. Sitzungberichte der Gesellschaft Naturforschender Freund zu Berlin, 3: 35-41.

Yflaar, B.Z. and Olivera, A. 2003. Utilização de náuplios de "branchoneta" Dendrocephalus brasiliensis (Pesta, 1921) na alimentação de larvas do "camarão cinza" Litopenaeus vannamei (Boone, 1931). Acta Scientiarum - Biological Sciences, 25(2): 299-307. 